\title{
Hierarchical glucocorticoid-endocannabinoid interplay regulates the activation of the nucleus accumbens by insulin
}

Running title: Insulin action on accumbal glucose uptake

Bárbara S. Pinheiro ${ }^{\text {a, } 1,3}$, Cristina Lemos ${ }^{\text {a, } 1,2}$, Fernanda Neutzling-Kaufmann ${ }^{\text {a }}$, Joana M. Marques ${ }^{\text {a }}$, Carla S. da Silva-Santos ${ }^{\text {a }}$, Eugénia Carvalho ${ }^{\mathrm{a}}$, Ken Mackie ${ }^{\mathrm{b}}$, Ricardo J. Rodrigues ${ }^{\text {a, c }}$, Rodrigo A. Cunha ${ }^{\text {a, d }}$, Attila Köfalvi ${ }^{\text {a, c, * }}$

${ }^{a}$ CNC; Center for Neuroscience and Cell Biology of Coimbra, University of Coimbra, 3004504 Coimbra, Portugal

${ }^{b}$ Department of Psychological and Brain Sciences, Gill Center for Biomolecular Science, Indiana University, Bloomington, Indiana, USA

c Institute for Interdisciplinary Research, University of Coimbra, 3030-789 Coimbra, Portugal

${ }^{d}$ FMUC; Faculty of Medicine, University of Coimbra, 3004-504 Coimbra, Portugal

${ }^{1}$ Present address: Experimental Psychiatry Unit, Center for Psychiatry and Psychotherapy, Medical University Innsbruck, Austria

${ }^{2}$ These authors contributed equally to the work.

* Corresponding author. Laboratory of Neuromodulation and Metabolism, CNC; Center for Neuroscience and Cell Biology of Coimbra, Faculty of Medicine, University of Coimbra, 3004-504 Coimbra, Portugal. E-mail address: akofalvi@uc.pt (A. Köfalvi). 


\begin{abstract}
Abbreviations
$\left[{ }^{3} \mathrm{H}\right] \mathrm{DG}, \quad\left[{ }^{3} \mathrm{H}\right]$-2-deoxy-D-glucose; $\quad\left[{ }^{18} \mathrm{~F}\right] \mathrm{FDG}-\mathrm{PET}, \quad\left[{ }^{18} \mathrm{~F}\right]$-fluorodeoxyglucose-positron emission tomography; $\left[{ }^{3} \mathrm{H}\right] \mathrm{GABA}$, tritiated $\gamma$-aminobutyric acid; 2-AG, 2-arachidonoylglycerol; 3Rs, Replacement, Refinement and Reduction of Animals in Research; $\alpha, \beta H D 6 / 12$, $\alpha, \beta$ hydrolase domain-containing protein 6/12; ARRIVE, Animals in Research: Reporting In Vivo Experiments; $\mathrm{CB}_{1} \mathrm{R}(\mathrm{s})$, cannabinoid $\mathrm{CB}_{1}$ receptor(s); DAGL $\alpha$, sn-1-diacylglycerol lipase $\alpha$; dexa, dexamethasone; DMAQB1, demethylasterriquinone B1, DMSO, dimethylsulfoxide; DPM, disintegration per minute; DTT, dithiothreitol; FELASA, Federation for Laboratory Animal Science Associations; FR\%, fractional release expressed as percentage; GcR(s), glucocorticoid receptor(s); HEPES, 4-(2-hydroxyethyl)-1-piperazineethanesulfonic acid; IGF$1 \mathrm{R}(\mathrm{s})$, insulin-like growth factor-1 receptor(s), $\operatorname{IgG}_{2 \mathrm{~A}}$, immunoglobulin $\mathrm{G}_{2 \mathrm{~A}}$; InsR(s), insulin receptor(s); IOMeTAG, I-OMe-Tyrphostin AG 538; MAGL, monoacylglycerol lipase; McR(s), mineralocorticoid receptor(s); MOPS, 3-(N-morpholino)propanesulfonic acid; SDSPAGE, sodium dodecyl sulphate-polyacrylamide gel electrophoresis; THL, tetrahydrolipstatin; Tris, tris(hydroxymethyl)aminomethane; Triton-X 100, polyethylene glycol p-(1,1,3,3-tetramethylbutyl)-phenyl ether; WIN-2, WIN55212-2
\end{abstract}

\begin{abstract}
(244/250)
Here we asked if insulin activation of the nucleus accumbens in vitro is reflected by an increase in ${ }^{3} \mathrm{H}$-deoxyglucose $\left(\left[{ }^{3} \mathrm{H}\right] \mathrm{DG}\right)$ uptake, thus subserving a new model to study molecular mechanisms of central insulin actions. Additionally, we investigated the dependence of this insulin effect on endocannabinoids and corticosteroids, two major culprits in insulin resistance. We found that in acute accumbal slices, insulin ( 3 and $300 \mathrm{nM}$ but not at $0.3 \mathrm{nM}$ ) produced an increase in $\left[{ }^{3} \mathrm{H}\right] \mathrm{DG}$ uptake. The synthetic cannabinoid agonist, WIN55212-2 (500 nM) and the glucocorticoid dexamethasone $(10 \mu \mathrm{M})$, impaired insulin (300 $\mathrm{nM})$ action on $\left[{ }^{3} \mathrm{H}\right] \mathrm{DG}$ uptake. The glucocorticoid receptor (GcR) antagonist, mifepristone $(10 \mu \mathrm{M})$ prevented dexamethasone from inhibiting insulin's action. Strikingly, this antiinsulin action of dexamethasone was also blocked by two $\mathrm{CB}_{1}$ cannabinoid receptor $\left(\mathrm{CB}_{1} \mathrm{R}\right)$ antagonists, O-2050 (500 $\mathrm{nM})$ and SR141716A $(500 \mathrm{nM})$, as well as by tetrahydrolipstatin $(10 \mu \mathrm{M})$, an inhibitor of diacylglycerol lipases - the enzymes responsible for the synthesis of the endocannabinoid, 2-arachidonoyl-glycerol (2-AG). On the other hand, the blockade of the post-synaptic 2 -AG metabolizing enzymes, $\alpha, \beta$-serine hydrolase domain $6 / 12$ by WWL70 (1 $\mu \mathrm{M})$ also prevented the action of insulin, probably via increasing endogenous $2-\mathrm{AG}$ tone.
\end{abstract}


Additionally, an anti-insulin receptor (InsR) antibody immunoprecipitated $\mathrm{CB}_{1} \mathrm{Rs}$ from accumbal homogenates, indicating a physical complexing of $\mathrm{CB}_{1} \mathrm{Rs}$ with InsRs that supports their functional interaction. Altogether, insulin stimulates glucose uptake in the nucleus accumbens. Accumbal GcR activation triggers the synthesis of 2-AG that in turn binds to the known $\mathrm{CB}_{1} \mathrm{R}-\mathrm{InsR}$ heterodimer, thus impeding insulin signaling.

\section{Keywords}

2-arachidonoylglycerol; $\mathrm{CB}_{1} \mathrm{R}$ cannabinoid receptor; glucocorticoid receptor; glucose uptake; insulin; nucleus accumbens.

\section{Introduction}

Insulin signaling in the brain is crucial for both central and systemic metabolic homeostasis (Kleinridders et al., 2014; Kullmann et al., 2014). Research in humans and animals concluded that insulin influences glucose regulation in the forebrain (Duarte et al., 2012a). For instance, $\left[{ }^{18} \mathrm{~F}\right]$ FDG-PET studies documented that global cerebral glucose uptake rates can be stimulated by acute hyperinsulinemia only in patients with impaired glucose tolerance (Hirvonen et al. 2011), unless endogenous insulin production is suppressed in the healthy control group (Bingham et al., 2002). These findings suggest that even under normoinsulinemia, brain insulin levels are high enough to mask certain central effects of exogenous insulin. Notably though, mapping local metabolic rates in different brain areas, both increased and decreased glucose uptake have been reported in response to an acute bolus of insulin (Anthony et al., 2006). Local metabolic rates do not necessarily match changes in global metabolic rates: insulin for instance stimulates glucose uptake on average by $27 \%$ in the ventral striatum of healthy humans, and only by $13 \%$ in insulin resistant patients (Anthony et al. 2006).

The ventral striatum is called the nucleus accumbens in non-primate mammals, and is a major relay nucleus of the reward circuitry (Kenny, 2011). Insulin signals converge here that underlie palatable food preference and food reward (Volkow et al., 2008; Kenny, 2011; Kullmann et al., 2015). The modulation of mesoaccumbal transmitter release and synaptic plasticity is also crucial in drug-induced reward and reinforcement of drug abuse - including that of cannabis - which are highly dependent on frontal cortical-mesoaccumbal endocannabinoid signaling (Robbe et al., 2003; Maldonado et al., 2013; Covey et al., 2014). 
Consequently, food and drug addiction share common mechanisms (Volkow et al., 2008; Kenny, 2011), and insulin resistance is associated with the physical and functional deterioration of the nucleus accumbens, which exacerbates addictive behaviour including the increased intake of caloric and palatable food (Isganaitis and Lustig, 2005; Chen et al., 2013; O'Dell et al., 2014).

Various molecular mechanisms can hinder insulin signaling at insulin receptors (InsRs). For example, glucocorticoids are well known to cause insulin resistance and obesity (Andrews and Walker, 1999). Strikingly, a recent study revealed that glucocorticoids can trigger the metabolic syndrome by engaging endocannabinoid signaling in the periphery (Bowles et al., 2015). Glucocorticoid receptor (GcR) activation has also been reported to stimulate endocannabinoid synthesis at central synapses (Di et al., 2003; Hill and McEwen, 2009; Hill et al., 2011). The metabotropic $\mathrm{CB}_{1}$ cannabinoid receptor $\left(\mathrm{CB}_{1} \mathrm{R}\right)$ is the principal cognate receptor in the brain of the two most-studied endocannabinoids, anandamide and 2AG (Katona and Freund, 2012; Murataeva et al., 2014). The $\mathrm{CB}_{1} \mathrm{R}$ is present in the nucleus accumbens (Mátyás et al., 2006; Pickel et al., 2006; Winters et al., 2012). Remarkably, $\mathrm{CB}_{1} \mathrm{Rs}$ form functional and physical heterodimers with the $\beta$-chain of the InsRs in both pancreatic islets and neuronal cell lines (Dalton and Howlett, 2012; Kim et al., 2012), and cannabimimetics prevent insulin-induced autophosphorylation of the InsR $\beta$-chain and the consequent activation of the $\mathrm{PI}_{3} \mathrm{~K}$-Akt pathway.

Here we sought answers to two main questions, namely whether insulin also stimulates glucose uptake in the accumbal slice as it does in vivo (Anthony et al., 2006), and if the effect of insulin is influenced by glucocorticoid and endocannabinoid signaling. This would also support the use of in vitro $\left[{ }^{3} \mathrm{H}\right] \mathrm{DG}$ assays to study basic mechanisms of food intake regulation, providing a viable alternative to in vivo $\left[{ }^{18} \mathrm{~F}\right] \mathrm{FDG}-\mathrm{PET}$ studies.

\section{Materials and Methods}

\subsection{Ethics statement and animals}

All studies were conducted in accordance with the principles and procedures outlined as "3Rs" in the guidelines of EU (86/609/EEC), FELASA, and the National Centre for the 3Rs (the ARRIVE; Kilkenny et al., 2010). Studies were approved by the Animal Care Committee of the Center for Neuroscience and Cell Biology of the University of Coimbra, Portugal. We also applied the ARRIVE guideline for the design and execution of in vitro pharmacological 
experiments (see below), as well as for data management and interpretation (McGrath et al., 2010; Curtis et al., 2015).

Sixty-seven male Wistar rats purchased from Charles-River (Barcelona, Spain) at 6 weeks of age. Animals were housed on $12 \mathrm{~h}$ light on/off cycles under controlled temperature $\left(23 \pm 2{ }^{\circ} \mathrm{C}\right)$, and ad libitum access to food and water. All efforts were made to minimize the number of animals used and to minimize their stress and discomfort, and different rat tissues were shared for various ongoing studies.

\subsection{In vitro measurement of glucose uptake in accumbal slices}

Experiments were carried out as before, with some modifications (Lemos et al. 2012,2015). Before decapitation with a guillotine, rats were deeply anesthetized with halothane vapor in air, using $1 \mathrm{~mL}$ liquid halothane in a $9000 \mathrm{~cm}^{3}$-volume box. Rats were killed around 2:00 PM each experimental day to reduce potential circadian hormonal effects, and their brain was immediately placed in ice-cold Krebs-HEPES assay solution of the following composition: (in mM: $\mathrm{NaCl} 133, \mathrm{KCl} 3, \mathrm{KH}_{2} \mathrm{PO}_{4} 1.2, \mathrm{MgSO}_{4}$ 1.2, $\mathrm{CaCl}_{2}$ 2.5, $\mathrm{NaHCO}_{3}$ 25, glucose 5.5, HEPES 1.5, pH 7.4). The pairs of nuclei accumbens were rapidly dissected and $400 \mu \mathrm{m}$-thick transverse slices were cut parallel to the coronal plane with the help of a McIlwain tissue chopper, and the slices were gently separated in ice-cold assay solution (carboxygenated with $95 \% \mathrm{O}_{2}$ and $5 \% \mathrm{CO}_{2}$ ), then transferred and maintained at $37^{\circ} \mathrm{C}$ in a multichamber slice incubator with $50 \mathrm{~mL}$ of carboxygenated assay solution until the end of the experiment. Each container had separated nylon-mesh bottom wells to keep 4 accumbal slices from each of the three animals per experiment, i.e. each container had approximately 3.5-4.0 mg protein in 50 $\mathrm{mL}$ assay medium. Chemicals were added to the assay at different time-points as explained in Fig. 1A: the DAGL inhibitor, tetrahydrolipstatin $(10 \mu \mathrm{M})$, the GcR antagonist, mifepristone $(10 \mu \mathrm{M})$, and the mineralocorticoid receptor $(\mathrm{McR})$ antagonist, spironolactone $(10 \mu \mathrm{M})$ or their vehicle, DMSO $(0.1 \%)$ were added at the beginning of the 60 min recovery incubation period. The MAGL inhibitor, JZL184 $(1 \mu \mathrm{M})$, the $\alpha, \beta$ HD6/12 inhibitor, WWL70 $(1 \mu \mathrm{M})$, and the $\mathrm{CB}_{1} \mathrm{R}$-selective antagonists SR141716A (500 nM) and O-2050 (500 nM), and the IGF-1R antagonist, I-OMe-tyrphostin AG $538(5 \mu \mathrm{M})$ or their vehicle, DMSO $(0.1 \%)$ were added after 50 min recovery incubation. The synthetic cannabinoid agonist, WIN55212-2 (500 nM) and the glucocorticoid dexamethasone $(1$ and $10 \mu \mathrm{M})$ or their vehicle, DMSO $(0.1 \%)$ were added after 55 min recovery time, and demethylasterriquinone $\mathrm{B} 1(10 \mu \mathrm{M})$ or its vehicle, DMSO (0.1\%), as well as insulin ( 3 and $300 \mathrm{nM})$ were added after $60 \mathrm{~min}$ recovery time, i.e. 1 min before $\left[{ }^{3} \mathrm{H}\right]$-2-deoxyglucose $\left(\left[{ }^{3} \mathrm{H}\right] \mathrm{DG}\right.$; final concentration of $\left.1 \mathrm{nM}\right)$ administration. The 
slices were then incubated for more $30 \mathrm{~min}$, which is an optimal assay length to obtain good specific vs. total uptake with linear kinetics (Schmidt et al., 1989). Two-three randomly selected slices were incubated with $1 \mathrm{nM}\left[{ }^{3} \mathrm{H}\right] \mathrm{DG}$ on ice along with the main experiment, to determine non-specific extracellular label.

Upon completion of the uptake period, the slices were washed four times in ice-cold Krebs-HEPES solution for $5 \mathrm{~min}$ and transferred to $1 \mathrm{~mL} \mathrm{NaOH}(0.5 \mathrm{M})$ to dissolve them. An aliquot of $800 \mu \mathrm{L}$ was then assayed for ${ }^{3} \mathrm{H}$ in a Tricarb 2900TR $\beta$-counter (PerkinElmer Portugal [ILC, Lisbon, Portugal]), while the remaining solution was used for protein quantification by the bicinchoninic acid assay (Merck Biosciences, Germany). Specific tritium uptake was multiplied by a factor of $5.5 \times 10^{6}$ to estimate the total glucose uptake (corresponding to the concentration difference between D-glucose and $\left[{ }^{3} \mathrm{H}\right] \mathrm{DG}$ in the uptake medium).

\section{3. $\left[{ }^{3} \mathrm{H}\right] \mathrm{GABA}$ and $\left[{ }^{14} \mathrm{C}\right]$ glutamate release assays from accumbal slices}

Experiments were carried out as described earlier for striatal and hippocampal slices (Köfalvi et al., 2005; Bitencourt et al., 2015), with slight modifications. Accumbal slices were prepared as above, incubated at room temperature at carboxygenation for $60 \mathrm{~min}$ to allow their metabolic recovery (Lemos et al., 2012), and were then incubated (loaded) either with $\left[{ }^{3} \mathrm{H}\right] \mathrm{GABA}$ (specific activity, $60 \mathrm{Ci} / \mathrm{mmol}$; final concentration, $300 \mathrm{nM}$ ) or $\left[{ }^{14} \mathrm{C}\right]$ glutamate $(200 \mathrm{mCi} / \mathrm{mmol} ; 20 \mu \mathrm{M})$ for $10 \mathrm{~min}$, in Krebs-HEPES solution that also contained aminooxyacetic acid $(100 \mu \mathrm{M})$ - a dual inhibitor of glutamate decarboxylase and GABA transaminase - to prevent the metabolism of $\left[{ }^{3} \mathrm{H}\right] \mathrm{GABA}$ or $\left[{ }^{14} \mathrm{C}\right]$ glutamate, respectively. The slices were trapped by layers of Whatman GF/B filters, and superfused continuously at a rate of $0.8 \mathrm{~mL} / \mathrm{min}$ with Krebs-HEPES solution $\left(37^{\circ} \mathrm{C}\right)$ until the end of the experiments. Upon termination of a 10-min washout period, three 2-min samples were collected serving as baseline, and then insulin (300 nM) was superfused for $12 \mathrm{~min}$ in half of the chambers (the other half served as control) (Fig. 2). All treatments and controls were run in duplicate and

averaged as $n=1$. The $\left[{ }^{14} \mathrm{C}\right]$ and $\left[{ }^{3} \mathrm{H}\right]$ content of each superfusate sample and slice was counted by a dual-label protocol using a Tricarb $\beta$-counter (Perkin-Elmer). DPM values were normalized to the slice content as fractional release (FR\%), i.e. the percent of actual content in the effluent as a function of the total content. The calculation for drug (insulin) effect on the baseline can be found in Köles et al. (2013). 


\subsection{Immunoprecipitation assays}

Immunoprecipitation assays of the $\mathrm{CB}_{1} \mathrm{R}$ were carried out essentially as previously described (Marques et al., 2013; Ferreira et al., 2015). After 55 min recovery, WIN55212-2 (500 nM), and 5 min later, insulin $(300 \mathrm{nM})$ were added to the bath of the accumbal slices, which were left for more $15 \mathrm{~min}$ to stimulate the formation of receptor heterodimers. The slices were then collected and proteins were extracted as before, and subsequently incubated with $50 \%$ slurry protein A-Sepharose (GE Healthcare Europe $\mathrm{GmbH}$, Carnaxide, Portugal) for $3 \mathrm{~h}$ at $4^{\circ} \mathrm{C}$ to eliminate non-specific binding. After incubation, the pre-cleared supernatants containing 700 $\mu \mathrm{g}$ of protein were incubated overnight with rotation at $4^{\circ} \mathrm{C}$ with $8 \mu \mathrm{g}$ rabbit polyclonal antiInsR C-terminal antibody (Sigma, SAB4501558) previously linked to protein-A sepharose (GE Healthcare), in the presence of $1 \%$ bovine serum albumin (Sigma-Aldrich Portugal, Sintra, Portugal) and protease inhibitors (Roche Diagnostics, Basel, Switzerland). The beads were washed three times with isolation buffer containing $150 \mathrm{mM} \mathrm{KCl}, 20 \mathrm{mM}$ MOPS, $1 \%$ Triton X-100 (pH 7.4), and resuspended in 6× diluted SDS-PAGE sample buffer $(0.35 \mathrm{M}$ Tris, 30\% glycerol, 10\% SDS, 0.6 M DTT, 0.012\% bromophenol blue, $\mathrm{pH} 6.8$ ). Immune complexes were dissociated from the beads and denaturated by heating to $95{ }^{\circ} \mathrm{C}$ for $5 \mathrm{~min}$ and then separated by $10 \%$ SDS-polyacrilamide gel electrophoresis. Proteins were then transferred into nitrocellulose membranes (Panreac Química, Barcelona, España) and probed with goat polyclonal anti-CB $\mathrm{CB}_{1} \mathrm{C}$-terminal antibody (Rozenfeld and Levi, 2008; Bitencourt et al., 2015) and affinity purified rabbit polyclonal anti-InsR (Santa Cruz Biotechnology, sc711), diluted in blocking solution (Tris-buffered saline supplemented with $0.1 \%$ Tween-20 and 5\% milk). Membranes were incubated with a horseradish peroxidase (HRP)-conjugated goat anti-rabbit or rabbit anti-goat secondary antibody (Pierce, Thermo Fisher Scientific Inc., Darmstadt, Germany), followed by incubation with SuperSignal West Pico Chemiluminescent Substrate (Pierce, Thermo Fisher Scientific Inc., Darmstadt, Germany), visualized using a VersaDoc3000 apparatus (BioRad, Amadora, Portugal) and analyzed with ImageLab software (BioRad, Amadora, Portugal). A negative control containing the same amount of rabbit polyclonal IgG instead of the rabbit anti-InsR antibody was performed in parallel.

\subsection{Data presentation}

All data represent means \pm S.E.M. of " $n "$ observations (animals) in duplicates (release experiments) or uniplicates (uptake experiments). For data presentation and manipulation, we followed the rules of Curtis et al. (2015). Raw data were normalized to the control value 
measured from the same animal. Normalized data were tested for normal distribution by the Kolmogorov-Smirnov test. Statistical significance was determined by by one-sample $t$-test against the hypothetical value of $100(\%)$, and $P<0.05$ was accepted for significant difference, according to Curtis et al. (2015). Note that one-sample $t$-test does not take into account when more than one treatment is normalized to the same everyday control. Tests were performed using the GraphPad Prism 5.0 software package.

\subsection{Materials and chemicals}

[2,3- $\left.{ }^{3} \mathrm{H}(\mathrm{N})\right] \mathrm{GABA}\left(\left[{ }^{3} \mathrm{H}\right] \mathrm{GABA}\right.$; specific activity: $\left.60 \mathrm{Ci} / \mathrm{mmol}\right)$ and ${ }^{3} \mathrm{H}-2$-deoxy-D-glucose $\left(\left[{ }^{3} \mathrm{H}\right] \mathrm{DG} ; 60 \mathrm{Ci} / \mathrm{mmol}\right)$ and rimonabant (SR141716A) were bought from American Radiolabeled Chemicals, Inc, (Saint Louis, MO, USA). $\left[{ }^{14} \mathrm{C}\right]-U$-glutamate was from PerkinElmer Portugal (ILC Lisbon, Portugal). Dexamethasone human recombinant insulin, mifepristone, O-2050, spironolactone and WIN55212-2 mesylate were purchased from Tocris Biosciences, Bristol, UK. Aminooxyacetic acid, bovine serum albumin, DMSO, halothane, HEPES, I-OMe-tyrphostin AG 538, and 3-(N-morpholino)propanesulfonic acid (MOPS) were bought from Sigma-Aldrich, Sintra, Portugal. Inorganic reagents were obtained either from Merck Biosciences, Darmstadt, Germany or Sigma-Aldrich. Non-water soluble substances were diluted in DMSO and stored in aliquots at $-20^{\circ} \mathrm{C}$ until use at a 1:1000 dilution. Insulin was reconstituted with $\mathrm{HCl}$ (final concentration in the assay medium: 7 nanomoles of $\mathrm{HCl}$ per each nanomol of insulin), aliquoted and stored at $-20^{\circ} \mathrm{C}$.

\section{Results}

\subsection{Insulin receptor (InsR) activation stimulates glucose uptake in the accumbal slices}

The first 30 min of deoxyglucose uptake in the brain displays linear kinetics (Schmidt et al., 1989; Lemos et al., 2012). The mean glucose uptake value, as calculated from specific $\left[{ }^{3} \mathrm{H}\right] \mathrm{DG}$ uptake, amounted to $68.4 \pm 1.9 \mathrm{nmol} / \mathrm{mg}$ protein in the $30 \mathrm{~min}$ uptake period in the accumbal slices ( $\mathrm{n}=51$ rats, i.e. pooled from all control animals throughout the study). Onemin pretreatment with insulin at $3 \mathrm{nM}(\mathrm{n}=7)$ and at $300 \mathrm{nM}(\mathrm{n}=20)$, but not at $0.3 \mathrm{nM}(\mathrm{n}=$ 10) stimulated $\left[{ }^{3} \mathrm{H}\right] \mathrm{DG}$ uptake in the range of $20-24 \%(P<0.05)$ (Fig. 1B). Since we got more consistent results with $300 \mathrm{nM}$ insulin and we did not want to mitigate the possible 
involvement of the insulin-like growth factor receptor-1 (IGF-1R) in the following assays, we opted for using the concentration of $300 \mathrm{nM}$ for insulin throughout the study.

To test if insulin stimulated $\left[{ }^{3} \mathrm{H}\right] \mathrm{DG}$ uptake via the activation of IGF-1Rs, we pretreated the slices with the IGF-1R antagonist, I-OMe-Tyrphostin AG 538 (IOMeTAG) (5 $\mu \mathrm{M})$ for 10 min, which neither affected $\left[{ }^{3} \mathrm{H}\right] \mathrm{DG}$ uptake alone $(P>0.05$ vs. DMSO; Table 1$)$, nor prevented insulin from stimulating $\left[{ }^{3} \mathrm{H}\right] \mathrm{DG}$ uptake $(\mathrm{n}=8 ; P<0.05)$ (Fig. 1B). Demethylasterriquinone B1 (DMAQB1) $(10 \mu \mathrm{M})$, a selective activator of the Akt-pathway, specific to the InsR rather than other tyrosine kinases, also stimulated glucose uptake $(n=25$, $P<0.05$ ) (Fig. 1B), albeit lesser than insulin.

\subsection{Insulin does not stimulate glucose uptake via the modulation of synaptic activity}

An increase in either GABAergic or glutamatergic signaling (or both) is associated with greater glucose consumption in neurons and astrocytes (Ackerman et al., 1984; Pellerin and Magistretti, 1994). Thus, we next asked if insulin affects the release of fast neurotransmitters in the accumbal slices. In fact, insulin receptors and insulin receptor substrate p58/53 are present in CNS synapses (Abbot et al., 1999), and insulin is known to affect synaptic communication in the brain (McGregor et al., 2015). We therefore loaded accumbal slices with $\left[{ }^{3} \mathrm{H}\right] \mathrm{GABA}$ and $\left[{ }^{14} \mathrm{C}\right]$ glutamate, and subsequently, measured the outflow of these two radiolabeled neurotransmitters under insulin superfusion. As Fig. 2 demonstrates, insulin (300 $\mathrm{nM}$ ) did not affect the resting release of the two neurotransmitters (net changes for GABA, $0.020 \pm 0.022 \mathrm{FR} \%, \mathrm{n}=4, P>0.05$ vs. $0 \mathrm{FR} \%$ change; and net changes for glutamate, $0.18 \pm$ $0.55 \mathrm{FR} \%, \mathrm{n}=4, P>0.05$ vs. $0 \mathrm{FR} \%$ change). Hence, it is unlikely that insulin stimulates glucose uptake via the stimulation of fast synaptic transmission in the accumbal slice. Instead, insulin perhaps directly stimulates cellular $\left[{ }^{3} \mathrm{H}\right] \mathrm{DG}$ uptake in the nucleus accumbens.

\subsection{Glucocorticoid receptor (GcR) activation prevents insulin from stimulating glucose} uptake

Glucocorticoids are well known to impair insulin signaling (Andrews and Walker, 1999). We next asked if the effect of insulin in accumbal slices is also hindered by a glucocorticoid. Five min pretreatment of the slices with dexamethasone $(1$ and $10 \mu \mathrm{M})$ did not affect resting $\left[{ }^{3} \mathrm{H}\right] \mathrm{DG}$ uptake (Table 1) but prevented insulin $(300 \mathrm{nM})$ from stimulating $\left[{ }^{3} \mathrm{H}\right] \mathrm{DG}$ uptake (n $=6 ; P>0.05$ for both concentrations of dexamethasone, vs DMSO CTRL) (Fig. 3). The GcR antagonist, mifepristone $(10 \mu \mathrm{M})$ also had no effect on $\left[{ }^{3} \mathrm{H}\right] \mathrm{DG}$ uptake per se (Table 1$)$, but 
antagonized the action of dexamethasone and restored insulin-stimulated $\left[{ }^{3} \mathrm{H}\right] \mathrm{DG}$ uptake $(\mathrm{n}=$ 11; $P<0.05$ vs DMSO CTRL) (Fig. 3). Interestingly, the mineralocorticoid receptor (McR) antagonist, spironolactone $(10 \mu \mathrm{M})$ (Fig. 3) stimulated $\left[{ }^{3} \mathrm{H}\right] \mathrm{DG}$ uptake by $21 \%(P<0.05)$ on its own (Table 1), but it failed to antagonize the anti-insulin action of dexamethasone, as concluded from the normalization of the effect of the simultaneous treatment of insulin + dexamethasone + spironolactone to spironolactone alone $(\mathrm{n}=12 ; \mathrm{P}>0.05)($ Fig. 3). Thus, we conclude that it is the GcR, rather than the McR that impairs the stimulation of accumbal $\left[{ }^{3} \mathrm{H}\right] \mathrm{DG}$ uptake by insulin.

\section{4. $C B_{1}$ cannabinoid receptors mediate the anti-insulin action of GcRs}

The $\mathrm{CB}_{1} \mathrm{R}$ has been shown to inhibit InsR signaling via heterodimer formation between the receptors both in a neuronal and a pancreatic $\beta$-cell line (Dalton and Howlett, 2012; Kim et al., 2012). Thus, we asked if $\mathrm{CB}_{1} \mathrm{R}$ ligands affect resting and insulin-stimulated glucose uptake. Neither the potent synthetic cannabinoid agonist, WIN55212-2 (500 nM) nor the two $\mathrm{CB}_{1} \mathrm{R}$-selective antagonists, O-2050 (500 $\left.\mathrm{nM}\right)$ and SR141716A (500) affected accumbal glucose uptake per se (Table 1). However, a 5-min-preincubation with WIN55212-2 ( $\mathrm{n}=11$; $P>0.05$ vs DMSO CTRL) prevented insulin from stimulating glucose uptake in the accumbal slices (Fig. 4). It has been previously proposed that endocannabinoids can mediate some synaptic actions of glucocorticoids (Di et al., 2003, 2005; Hill et al., 2011), and we recently found in the cerebral cortex and the hippocampus that post-synaptic GcR immunoreactivity co-localizes with DAGLa (Bitencourt et al., 2015), the major cerebral isoform of diacylglycerol lipase, which synthesizes the endocannabinoid, 2-AG (Murataeva et al., 2014). Furthermore, these co-localizing protein complexes are apposed to presynaptic $\mathrm{CB}_{1} \mathrm{R}$-positive elements, thus bolstering the idea that $\mathrm{GcR}$ activation can stimulate $\mathrm{CB}_{1}$ Rs via trans-synaptic 2-AG signaling (Di et al., 2003, 2005; Hill and McEwen, 2009). To test if a similar mechanism is accountable for the anti-insulin effect of dexamethasone, we first pretreated the slices with the $\mathrm{CB}_{1} \mathrm{R}$-selective antagonists, O-2050 $(\mathrm{n}=6)$ or SR141716A $(\mathrm{n}=8)$, and 5 min later added dexamethasone $(10 \mu \mathrm{M})$. Indeed, both $\mathrm{CB}_{1} \mathrm{R}$ antagonists successfully restored the stimulatory action of insulin (Fig. 4). Of note, SR141716A pretreatment almost doubled the effect of insulin $(35.6 \pm 7.8 \%$ stimulation over DMSO control; $P<0.01)$, which is probably due to the inverse agonist properties of this antagonist.

To prove that the identity of the endocannabinoid underlying dexamethasone's action was indeed 2-AG, we preincubated the slices with tetrahydrolipstatin $(10 \mu \mathrm{M})$, which inhibits 
DAGL isoforms responsible for $\mathrm{CB}_{1} \mathrm{R}$ activation in the brain (Palomäki et al., 2007). While tetrahydrolipstatin had no effect alone (Table 1), it restored the $\sim 20 \%$ stimulation of glucose uptake by insulin in the presence of dexamethasone (n $=8 ; P<0.05$ vs. DMSO CTRL) (Fig. 4). It is believed that synaptic $2-A G$ is constantly generated at a basal rate, contributing to tonic $\mathrm{CB}_{1} \mathrm{R}$ signaling (Lee et al., 2015), and 2-AG is removed by major metabolizing enzymes, MAGL and $\alpha, \beta$ HD6/12 (Murataeva et al., 2014). Hence, we pretreated the slices either with the MAGL inhibitor, JZL184 $(1 \mu \mathrm{M})$ or with the $\alpha, \beta$ HD6/12 inhibitor, WWL70 (1 $\mu \mathrm{M})$. These inhibitors did not significantly affect glucose uptake on their own (Table 1), and MAGL inhibition still permitted insulin to stimulate glucose uptake in the slices (by $22 \% ; n=$ $5 ; P<0.01)$. However, the blockade of $\alpha, \beta$ HD6/12 abolished the action of insulin $(\mathrm{n}=5 ; P>$ 0.05 vs DMSO alone) (Fig. 4).

These pharmacological data together with the previously reported ability of the $\mathrm{CB}_{1} \mathrm{R}$ to heterodimerize with the InsR (Dalton and Howlett, 2012; Kim et al., 2012) strongly suggest a physical association between InsRs and $\mathrm{CB}_{1}$ Rs here in the nucleus accumbens. To prove this, we co-incubated accumbal slices with insulin (300 nM) and WIN55212-2 (500 nM) for 15 min with the aim of stimulating heterodimerization (Kim et al., 2012), then extracted the membrane proteins, and made an attempt to pull the $\mathrm{CB}_{1} \mathrm{R}$ down with an anti-InsR $\beta$-chain antibody. Indeed, as Fig. 5 illustrates, the $\mathrm{CB}_{1} \mathrm{R}$ was immunoprecipitated with an anti-InsR antibody, thus providing evidence for the coexistence of a both the $\mathrm{CB}_{1} \mathrm{R}$ and the InsR in a common protein complex in the rat nucleus accumbens.|

\section{Discussion}

The novel findings in this study indicate that insulin stimulates glucose uptake in the rat accumbal slice in vitro via insulin receptor (InsR) activation. Certainly, this is consistent with an earlier in vivo $\left[{ }^{18} \mathrm{~F}\right] \mathrm{FDG}-\mathrm{PET}$ study in humans (Anthony et al., 2006), thus documenting that studying insulin action in rat accumbal slices is a viable alternative approach that may be useful for dissecting mechanisms. Furthermore, glucocorticoid receptor (GcR) activation triggers the release of the endocannabinoid 2-AG, which in turn binds to $\mathrm{CB}_{1}$ cannabinoid receptors $\left(\mathrm{CB}_{1} \mathrm{Rs}\right)$ that form heterodimers with InsRs. While $\mathrm{CB}_{1} \mathrm{R}$ activation per se does not affect accumbal glucose uptake, it prevents insulin from stimulating glucose uptake.

Insulin and its receptors have been found throughout the brain, with their highest density in brain areas involved in the control of food intake (Havrankova et al., 1978; Pacold and Blackard, 1979). Cerebral insulin levels are dozens of times higher than those in the blood, 
which cannot be explained solely by a putative concentrating insulin transport from the circulation into the brain, and indeed, local cerebral insulin synthesis has been identified, at least in neurons (Havrankova et al., 1978; Clarke et al., 1986; Devaskar et al., 2004; Ghasemi et al., 2013; Molnár et al., 2014). We conclude that insulin stimulated glucose uptake in the accumbal slices via the activation of InsRs rather than IGF-1Rs, based on the following observations: Insulin binds to the InsR with a $K_{\mathrm{d}}$ of $0.4 \mathrm{nM}$ and is $13-32$-fold less potent at IGF-1Rs in the rat brain (Werther et al., 1987, 1989). In fact, insulin already reached maximal effect at $3 \mathrm{nM}$ in our assay, but even the effect of $300 \mathrm{nM}$ insulin was insensitive to IGF-1R blockade. Finally, the selective insulin receptor activator, DMAQB1 also stimulated glucose uptake, although much less efficaciously. This latter discrepancy can be due to the fact that we used this insulinomimetic at a concentration close to its $\mathrm{EC}_{50}$, or perhaps to that this ligand only activates the $\mathrm{PI}_{3} \mathrm{~K}-\mathrm{Akt}$ pathway amongst the various second messenger systems associated with the InsR (Webster et al., 2003) which might not be enough for maximal effect.

The InsR is widely distributed in the mammalian brain (Pacold and Blackard, 1979; Folli et al., 1994; Schulingkamp et al., 2000), including the nucleus accumbens (Kleinridders et al., 2014), with highest levels in the shell of the accumbens among the striatal regions (Werther et al., 1987). Cerebral InsRs play a major role in the regulation of the energy metabolism of the whole body (Brüning et al., 2000; Varela and Horvath, 2012). InsR activation can also stimulate local and global rates of cerebral glucose metabolism, but only a few studies have documented these findings (Bingham et al., 2002; McNay et al., 2010).

The exact cellular distribution of InsRs has not yet been investigated in the nucleus accumbens. However, studies in brain cell cultures provided (often circumstantial) evidence that insulin may directly stimulate glucose uptake in both neurons (Benomar et al., 2006; Uemura and Greenlee 2006) and astrocytes (Clarke et al., 1984; Werner et al., 1989; Kum et al., 1992).

Insulin may also modulate cerebral energy metabolism via the regulation of the activity of the circuitry. The stimulation of either GABAergic or glutamatergic signalling is indeed associated with increased glucose uptake in neurons and astrocytes (Ackerman et al., 1984; Pellerin and Magistretti, 1994), supporting the notion of activity-dependent metabolic coupling in the brain (Patel et al., 2014; Lundgaard et al., 2015). There is evidence for modulation of excitatory synaptic transmission by insulin $(500 \mathrm{nM})$ in the ventral tegmental area, which occurs trans-synaptically, because it involves insulin-mediated endocannabindoid release onto presynaptic glutamatergic terminals (Labouèbe et al., 2013; Liu et al., 2013). 
Insulin can also affect synaptic transmission by modulating AMPA- and NMDA-dependent synaptic plasticity, which is manifested post-synaptically (Huang et al., 2004; Costello et al., 2012). In our hands, insulin did not affect the resting extracellular GABA and glutamate levels in the accumbal slices. Hence, it is unlikely that insulin stimulated glucose uptake in the accumbal slice via the modulation of the fast synaptic transmission.

Alternatively, insulin could act through neuromodulation, and dopamine is the major neuromodulator of the nucleus accumbens. Accumbal dopamine release accompanies the hedonic rather than the nutritional value of sugar intake (Tellez et al., 2016). Importantly, both systemic insulin injection (Potter et al., 1999) and in vitro insulin application on acute brain slices (Stouffer et al., 2015) increased accumbal dopamine release, which is consistent with the hypothesis that insulin evokes reward and satiety responses. In line with this evidence, a fresh publication suggests that in vivo $\mathrm{CB}_{1} \mathrm{R}$ antagonism by $\mathrm{AM} 6527$ produces behaviors more consistent with satiety than reduced reward value (Thompson et al., 2016). Indeed, this is what we would expect to see if $\mathrm{CB}_{1} \mathrm{R}$ antagonism in the nucleus accumbens facilitates insulin signaling in vivo.

Another study, however, reported in the ventral tegmentum that insulin decreased the excitatory drive via endocannabinoid release onto the dopaminergic efferents (Labouèbe et al., 2013), which is expected to decrease dopaminergic activity in the target nucleus accumbens. This contradiction may be resolved by assuming a putative local accumbal mechanism that increases extracellular dopamine levels even if the firing of the input terminals is decreased. One possible scenario is that insulin in the presence of low ambient GABA levels inhibits the major neuronal $\mathrm{GABA}_{\mathrm{A}}$ receptor subtype (Williams, 2008). In the rat nucleus accumbens, $\mathrm{GABA}_{\mathrm{A}}$ receptor activation indeed reduces dopamine release (Sperlágh et al., 2009), thus insulin may presynaptically disinhibit accumbal dopamine release. Accumbal $\mathrm{CB}_{1} \mathrm{Rs}$ are predominantly confined to GABAergic nerve terminals (Mátyás et al., 2006). Strikingly, the activation of these presynaptic $\mathrm{CB}_{1} \mathrm{Rs}$ also can disinhibit accumbal dopamine release via the reduction of GABA release (Sperlágh et al., 2009). At the moment, we can not exclude the possibility that insulin stimulated glucose uptake via dopaminergic mechanisms in the accumbal slices, although the chance for that is remote: $\mathrm{CB}_{1}$ Rs do not modulate accumbal dopamine release directly (Sperlágh et al., 2009), and $\mathrm{CB}_{1} \mathrm{R}$ activation acted inversely to insulin on glucose uptake, while both insulin and endocannabinoids are expected to increase accumbal dopamine efflux. Nevertheless, there is a lack of information on how dopamine might modulate glucose metabolism in the brain, and earlier studies using L-DOPA also reported inconclusive data (Barash et al., 1985). This 
means that even if insulin acts through dopamine to influence glucose uptake, a serious additional effort is required to sufficiently settle the intricate interaction among neuromodulators and accumbal energy metabolism.

We next observed that acute GcR activation prevented insulin from stimulating glucose uptake, i.e. caused insulin resistance. While in the periphery, it is well-known that glucocorticoids impair insulin sensitivity (Andrews and Walker, 1999; Barbera et al., 2001), the present study provides evidence that this phenomenon holds true for the brain, too. If so, it may partly explain the detrimental effects of long-term unpredictable stress, chronic glucocorticoid treatment and Cushing-syndrome on brain structure and function (Belanoff et al., 2001; Sotiropoulos et al., 2008; Cattaneo and Riva, 2015). Importantly, these outcomes of chronic overactivation of GcRs (i.e. obesity/diabetes, mood disorders and dementias including Alzheimer's disease) fully coincide with the neuropsychiatric profile of cerebral insulin resistance (Duarte et al., 2012a, Ghasemi et al., 2013). Curiously, it has been known for decades that adrenalectomy rapidly increases glucose uptake in the brain in a matter of hours (Kadekaro et al., 1988). It is tempting to find parallelism with our data that spironolactone stimulated glucose uptake in the accumbal slice, because the McRs are "always occupied" by corticosteroids while GcRs are subject to phasic activation (Funder, 1996). But taken that animal manipulation and anesthesia always trigger phasic GcR activation in the brain (Gil et al., 2007), the rescue of insulin-stimulated glucose uptake is equivalently possible as an underlying mechanism for the adrenalectomy-induced increased cerebral glucose uptake observed by Kadekarko et al. (1988).

Last but not least, we documented that the DAGL/2-AG/CB $\mathrm{R}$ axis mediated the antiinsulin effect of dexamethasone. In the periphery, it has been shown that chronic treatment with a high dose of corticosterone triggers metabolic syndrome in mice within weeks (Bowles et al., 2015). This is accompanied with an increase in circulating anandamide levels, and can be prevented by genetic or chemical ablation of the $\mathrm{CB}_{1} \mathrm{R}$ (Bowlest et al., 2015). Interestingly, in the hypothalamus of these animals, a significant decrease in 2-AG levels was observed, which may reflect desensitization as a result of chronic DAGL stimulation. Nevertheless, glucocorticoids do increase endocannabinoid release acutely in the hypothalamus to inhibit the glutamatergic input to the parvocellular neurons of the paraventricular nucleus (Di et al., 2003), and so they do in the medial prefrontal cortex (Hill et al., 2011). This can be achieved by post-synaptic DAGL $\alpha$ activation adjacent to GcR in the frontal cortex (Bitencourt et al., 2015), apposing to $\mathrm{CB}_{1} \mathrm{R}$-positive nerve terminals. Whether in the nucleus accumbens, the $\mathrm{CB}_{1} \mathrm{R}$-InsR heterodimers are located to cells different from those which bear GcR and 
DAGL $\alpha$ cannot be determined by our study. It has been previously established that the $\mathrm{CB}_{1} \mathrm{R}$ is predominantly neuronal (axonal and dendritic) in the nucleus accumbens (Pickel et al., 2006). It is quite likely that the MSN dendrites are also endowed with GcR and DAGL $\alpha$, as their antisera give predominant post-synaptic labeling in the cerebral cortex and the hippocampus (Bitencourt et al., 2015). Assuming that these neuronal $\mathrm{CB}_{1} \mathrm{Rs}$ impair the action of insulin, it is tempting to conclude that insulin stimulates glucose uptake in the MSN. Still, conclusive evidence is required to disprove the involvement of glial cells.

As of interest, two functional types of $\mathrm{CB}_{1} \mathrm{R}$ antagonists can be distinguished. One is a neutral antagonist such as $\mathrm{O}-2050$, and it is believed that it only prevents phasic $\mathrm{CB}_{1} \mathrm{R}$ activation upon stimulated endocannabinoid release, while SR141716A (rimonabant, Acomplia) also prevents the constitutive activity of the $\mathrm{CB}_{1} \mathrm{R}$ (Pertwee, 2005; Meye et al., 2013). This scenario is consistent with what we found in our experimental model with the overt facilitation of insulin action. Notably, the action of SR141716A (Acomplia) on human food intake is initially dependent on the blockade of central $\mathrm{CB}_{1} \mathrm{Rs}$ (Horvath, 2006; Matias et al., 2008). However, neutral $\mathrm{CB}_{1} \mathrm{R}$ antagonists are just as good for reducing food intake as the inverse agonist, SR141716A, but without affecting constitutive $\mathrm{CB}_{1} \mathrm{R}$ signaling (Meye et al., 2013). Whether this beneficial central $\mathrm{CB}_{1} \mathrm{R}$ antagonist action on calorie intake involves the nucleus accumbens and insulin signaling has not been fully elucidated, but is highly likely. This is because endocannabinoids and insulin in the mesoaccumbal reward system play a crucial role in palatable and caloric food intake (Potter et al., 1999; Volkow et al., 2008; Daws et al., 2011; Kenny et al., 2011; Meye and Adam, 2014; Thompson et al., 2016).

Taken together, our report here is the first to find a link among glucocorticoids, endocannabinoids and insulin signaling in the brain, specifically in the nucleus accumbens. The model is testable in vivo too, and may help us to better understand the intricate interaction among these signaling systems in the control of calorie intake as well as in the pathogenesis of obesity, and other neuropsychiatric disorders.

\section{Acknowledgments}

This work was supported by grants from the Fundação para a Ciência e a Tecnologia to A.K. (PTDC/SAU-OSM/105663/2008 and PTDC/SAU-NEU/100729/2008), to R.A.C. (PTDC/SAU-NSC/122254/2010), to E.C. (PTDC/SAU-OSM/104124/2008) and to R.J.R. (EXPL/NEU-NMC/0671/2012); as well as from DARPA to R.A.C. (W911NF-10-1-0059). This work was also supported by Programa Mais Centro under project CENTRO-07-ST24- 
FEDER-002006, COMPETE, PEst-C/SAU/LA0001/2013-2014, and the strategic project UID/NEU/04539/2013 as well as the US National Institutes of Health to K.M. (DA011322 and DA021696). The authors are grateful to Drs. Ana Burgeiro and Liane Moura for excellent help.

\section{Conflicts of interest}

None.

\section{List of Author Contribution}

Study design: AK. Neurochemical assays: BSP, CL, FNK, CSS, AK, EC. Immunoprecipitation: JMM, RJR, KM, BSP, CSS. Financing: AK, RAC. First draft: AK. Final form of the manuscript: all authors.

\section{References}

Abbott, M.A., Wells, D.G., Fallon, J.R. (1999). The insulin receptor tyrosine kinase substrate p58/53 and the insulin receptor are components of CNS synapses. J Neurosci. 19, 73007308.

Ackermann, R.F., Finch, D.M., Babb, T.L., Engel, J., 1984. Increased glucose metabolism during long-duration recurrent inhibition of hippocampal pyramidal cells. J. Neurosci. 4, $251-264$

Andrews, R.C., Walker, B.R., 1999. Glucocorticoids and insulin resistance: old hormones, new targets. Clin. Sci. (Lond). 96, 513-523. doi:10.1042/cs0960513

Anthony, K., Reed, L.J., Dunn, J.T., Bingham, E., Hopkins, D., Marsden, P.K., Amiel, S.A., 2006. Attenuation of insulin-evoked responses in brain networks controlling appetite and reward in insulin resistance: the cerebral basis for impaired control of food intake in metabolic syndrome? Diabetes 55, 2986-2992. doi:10.2337/db06-0376

Baptista, F.I., Gaspar, J.M., Cristóvão, A., Santos, P.F., Köfalvi, A., Ambrósio, A.F., 2011. Diabetes induces early transient changes in the content of vesicular transporters and no 
major effects in neurotransmitter release in hippocampus and retina. Brain Res. 1383, 257-269. doi:10.1016/j.brainres.2011.01.071

Barash, V., Globus, M., Melamed, E., Weidenfeld, J., 1985. Effect of L-DOPA on glucose oxidation and incorporation into glycogen in discrete brain regions of the rat. Brain. Res. $335,347-349$.

Barbera, M., Fierabracci, V., Novelli, M., Bombara, M., Masiello, P., Bergamini, E., De Tata, V., 2001. Dexamethasone-induced insulin resistance and pancreatic adaptive response in aging rats are not modified by oral vanadyl sulfate treatment. Eur. J. Endocrinol. 145, 799-806. doi:10.1530/eje.0.1450799

Belanoff, J.K., Gross, K., Yager, A., Schatzberg, A.F., 2001. Corticosteroids and cognition. J. Psychiatr. Res. 35, 127-145. doi:10.1016/S0022-3956(01)00018-8

Benomar, Y., Naour, N., Aubourg, A., Bailleux, V., Gertler, A., Djiane, J., Guerre-Millo, M., Taouis, M., 2006. Insulin and leptin induce Glut4 plasma membrane translocation and glucose uptake in a human neuronal cell line by a phosphatidylinositol 3-kinasedependent mechanism. Endocrinology 147, 2550-2556. doi:10.1210/en.2005-1464

Bingham, E.M., Hopkins, D., Smith, D., Pernet, A., Hallett, W., Reed, L., Marsden, P.K., Amiel, S.A., 2002. The role of insulin in human brain glucose metabolism: an ${ }^{18}$ fluorodeoxyglucose positron emission tomography study. Diabetes 51, 3384-3390. doi:10.2337/diabetes.51.12.3384

Bitencourt, R.M., Alpár, A., Cinquina, V., Ferreira, S.G., Pinheiro, B.S., Lemos, C., Ledent, C., Takahashi, R.N., Sialana, F.J., Lubec, G., Cunha, R.A., Harkany, T., Köfalvi, A., 2015. Lack of presynaptic interaction between glucocorticoid and $\mathrm{CB}_{1}$ cannabinoid receptors in GABA- and glutamatergic terminals in the frontal cortex of laboratory rodents. Neurochem. Int. doi:10.1016/j.neuint.2015.07.014

Bowles, N.P., Karatsoreos, I.N., Li, X., Vemuri, V.K., Wood, J.-A., Li, Z., Tamashiro, K.L.K., Schwartz, G.J., Makriyannis, A.M., Kunos, G., Hillard, C.J., McEwen, B.S., Hill, M.N., 2015. A peripheral endocannabinoid mechanism contributes to glucocorticoidmediated metabolic syndrome. Proc. Natl. Acad. Sci. U. S. A. 112, 285-290. doi:10.1073/pnas. 1421420112 
Brüning, J.C., Gautam, D., Burks, D.J., Gillette, J., Schubert, M., Orban, P.C., Klein, R., Krone, W., Müller-Wieland, D., Kahn, C.R., 2000. Role of brain insulin receptor in control of body weight and reproduction. Science 289, 2122-2125. doi:10.1126/science.289.5487.2122

Cattaneo, A., Riva, M.A., 2015. Stress-induced mechanisms in mental illness: A role for glucocorticoid signalling. J. Steroid Biochem. Mol. Biol. doi:10.1016/j.jsbmb.2015.07.021

Chen, Z., Li, J., Liu, M., Ma, L., 2013. Volume changes of cortical and subcortical reward circuitry in the brain of patients with type 2 diabetes mellitus. Nan Fang Yi Ke Da Xue Xue Bao 33, 1265-1272. doi:10.3969/j.issn.1673-4254.2013.09.03

Clarke, D., Mudd, L., Boyd, F., Fields, M., Raizada, M. K., 1986. Insulin is released from rat brain neuronal cells in culture. J. Neurochem. 47, 831-836.

Clarke, D.W., Boyd, F.T., Kappy, M.S., Raizada, M.K., 1984. Insulin binds to specific receptors and stimulates 2-deoxy-D-glucose uptake in cultured glial cells from rat brain. J. Biol. Chem. 259, 11672-11675.

Costello, D.A., Claret. M., Al-Qassab, H., Plattner, F., Irvine, E.E., Choudhury, A.I., Giese, K.P., Withers, D.J., and Pedarzani, P., 2012. Brain deletion of insulin receptor substrate 2 disrupts hippocampal synaptic plasticity and metaplasticity. PLoS One 7(2):e31124. doi: 10.1371/journal.pone.0031124.

Covey, D.P., Wenzel, J.M., Cheer, J.F., 2014. Cannabinoid modulation of drug reward and the implications of marijuana legalization. Brain Res. doi:10.1016/j.brainres.2014.11.034

Curtis, M.J., Bond, R.A., Spina, D., Ahluwalia, A., Alexander, S.P., Giembycz, M.A., Gilchrist, A., Hoyer, D., Insel, P.A., Izzo, A.A., Lawrence, A.J., MacEwan, D.J., Moon, L.D., Wonnacott, S., Weston. A,H., McGrath, J.C., 2015. Experimental design and analysis and their reporting: new guidance for publication in BJP. Br. J. Pharmacol. 172:3461-3471. doi: 10.1111/bph.12856.

Dalton, G.D., Howlett, A.C., 2012. Cannabinoid $\mathrm{CB}_{1}$ receptors transactivate multiple receptor tyrosine kinases and regulate serine/threonine kinases to activate ERK in neuronal cells. Br. J. Pharmacol. 165, 2497-2511. doi:10.1111/j.1476-5381.2011.01455.x 
Daws, L.C., Avison, M.J., Robertson, S.D., Niswender, K.D., Galli, A., Saunders, C., 2011. Insulin signaling and addiction. Neuropharmacology 61, 1123-1128. doi:10.1016/j.neuropharm.2011.02.028

Devaskar, S. U., Giddings, S., Rajakumar, P., Carnaghi, L., Menon, R., and Zahm. D., 1994. Insulin gene expression and insulin synthesis in mammalian neuronal cells. J. Biol. Chem. $269,8445-8454$.

Di, S., Malcher-Lopes, R., Halmos, K.C., Tasker, J.G., 2003. Nongenomic glucocorticoid inhibition via endocannabinoid release in the hypothalamus: a fast feedback mechanism. J. Neurosci. 23, 4850-4857.

Di, S., Malcher-Lopes, R., Marcheselli, V.L., Bazan, N.G., Tasker, J.G., 2005. Rapid glucocorticoid-mediated endocannabinoid release and opposing regulation of glutamate and gamma-aminobutyric acid inputs to hypothalamic magnocellular neurons. Endocrinology 146:4292-4301

Duarte, A.I., Moreira, P.I., Oliveira, C.R., 2012a. Insulin in central nervous system: more than just a peripheral hormone. J. Aging Res. doi:10.1155/2012/384017

Folli, F., Bonfanti, L., Renard, E., Kahn, C.R., Merighi, A., 1994. Insulin receptor substrate-1 (IRS-1) distribution in the rat central nervous system. J. Neurosci. Off. J. Soc. Neurosci. $14,6412-6422$.

Funder, J.W., 1996. Mineralocorticoid receptors in the central nervous system. J. Steroid Biochem. Mol. Biol. 56, 179-183.

Ghasemi, R., Haeri, A., Dargahi, L., Mohamed, Z., Ahmadiani, A., 2013. Insulin in the brain: sources, localization and functions. Mol. Neurobiol. 47, 145-171. doi:10.1007/s12035012-8339-9

Gil, A.G., Silván, G., Illera, J.C., 2007. Pituitary-adrenocortical axis, serum serotonin and biochemical response after halothane or isoflurane anaesthesia in rabbits. Lab. Anim. 41, 411-419. doi:10.1258/002367707782314274

Havrankova, J., Schmechel, D., Roth, J., Brownstein, M., 1978. Identification of insulin in rat brain. Proc. Natl. Acad. Sci. U. S. A. 75, 5737-5741. 
Hill, M.N., Hillard, C.J., McEwen, B.S., 2011. Alterations in corticolimbic dendritic morphology and emotional behavior in cannabinoid $\mathrm{CB}_{1}$ receptor-deficient mice parallel the effects of chronic stress. Cereb. Cortex 21, 2056-2064. doi:10.1093/cercor/bhq280

Hill, M.N., McEwen, B.S., 2009. Endocannabinoids: The silent partner of glucocorticoids in the synapse. Proc. Natl. Acad. Sci. U. S. A. 106, 4579-4580. doi:10.1073/pnas.0901519106

Hirvonen, J., Virtanen, K.A., Nummenmaa, L., Hannukainen, J.C., Honka, M.-J., Bucci, M., Nesterov, S.V., Parkkola, R., Rinne, J., Iozzo, P., Nuutila, P., 2011. Effects of insulin on brain glucose metabolism in impaired glucose tolerance. Diabetes 60, 443-447. doi:10.2337/db10-0940

Horvath, T.L. (2006). The unfolding cannabinoid story on energy homeostasis: central or peripheral site of action? Int. J. Obes. (Lond). 30, 1:S30-32.

Huang, C.C., Lee, C.C., Hsu, K.S., 2004. An investigation into signal transduction mechanisms involved in insulin-induced long-term depression in the CA1 region of the hippocampus. J. Neurochem. 89, 217-231.

Isganaitis, E., Lustig, R.H., 2005. Fast food, central nervous system insulin resistance, and obesity. Arterioscler. Thromb. Vasc. Biol. 25, 2451-2462. doi:10.1161/01.ATV.0000186208.06964.91

Kadekaro, M., Ito, M., Gross, P.M., 1988. Local cerebral glucose utilization is increased in acutely adrenalectomized rats. Neuroendocrinology 47, 329-334.

Katona, I., Freund, T.F., 2012. Multiple functions of endocannabinoid signaling in the brain. Annu. Rev. Neurosci. 35, 529-558. doi:10.1146/annurev-neuro-062111-150420

Kenny, P.J., 2011. Common cellular and molecular mechanisms in obesity and drug addiction. Nat. Rev. Neurosci. 12, 638-651. doi:10.1038/nrn3105

Kilkenny, C., Browne, W., Cuthill, I.C., Emerson, M., Altman, D.G., NC3Rs Reporting Guidelines Working Group, 2010. Animal research: reporting in vivo experiments: the ARRIVE guidelines. Br. J. Pharmacol. 160, 1577-1579. doi:10.1111/j.14765381.2010.00872.x 
Kim, W., Lao, Q., Shin, Y.-K., Carlson, O.D., Lee, E.K., Gorospe, M., Kulkarni, R.N., Egan, J.M., 2012. Cannabinoids induce pancreatic $\beta$-cell death by directly inhibiting insulin receptor activation. Sci. Signal. 5, ra23. doi:10.1126/scisignal.2002519

Kleinridders, A., Ferris, H.A., Cai, W., Kahn, C.R., 2014. Insulin action in brain regulates systemic metabolism and brain function. Diabetes 63, 2232-2243. doi:10.2337/db14-0568

Köfalvi, A., Rodrigues, R.J., Ledent, C., Mackie, K., Vizi, E.S., Cunha, R.A., Sperlágh, B., 2005. Involvement of cannabinoid receptors in the regulation of neurotransmitter release in the rodent striatum: a combined immunochemical and pharmacological analysis. J. Neurosci. 25, 2874-2884.

Köles, L., Garção, P., Zádori, Z.S., Ferreira, S.G., Pinheiro, B.S., da Silva-Santos, C.S., Ledent, C., Köfalvi, A., 2013. Presynaptic TRPV 1 vanilloid receptor function is age- but not $\mathrm{CB}_{1}$ cannabinoid receptor-dependent in the rodent forebrain. Brain. Res. Bull. 97, 126-135. doi: 10.1016/j.brainresbull.2013.06.007.

Kullmann, S., Heni, M., Fritsche, A., Preiss1, H., 2015. Insulin action in the human brain: evidence from neuroimaging studies. J. Neuroendocrinol. 27, 419-423. doi:10.1111/jne.12254

Kum, W., Zhu, S.Q., Ho, S.K., Young, J.D., Cockram, C.S., 1992. Effect of insulin on glucose and glycogen metabolism and leucine incorporation into protein in cultured mouse astrocytes. Glia 6, 264-268. doi:10.1002/glia.440060404

Labouèbe, G., Liu, S., Dias, C., Zou, H., Wong, J.C., Karunakaran, S., Clee, S.M., Phillips, A.G., Boutrel, B., Borgland, S.L., 2013. Insulin induces long-term depression of ventral tegmental area dopamine neurons via endocannabinoids. Nat. Neurosci. 16:300-308. doi: $10.1038 / \mathrm{nn} .3321$.

Lee, S.H., Ledri, M., Tóth, B., Marchionni, I., Henstridge, C.M., Dudok, B., Kenesei, K., Barna, L., Szabó, S.I., Renkecz, T., Oberoi, M., Watanabe, M., Limoli, C.L., Horvai, G., Soltesz, I., Katona, I., 2015. Multiple Forms of Endocannabinoid and Endovanilloid Signaling Regulate the Tonic Control of GABA Release. J. Neurosci. 35, 10039-10057. doi: 10.1523/JNEUROSCI.4112-14.2015. 
Lemos, C., Pinheiro, B.S., Beleza, R.O., Marques, J.M., Rodrigues, R.J., Cunha, R.A., Rial, D., Köfalvi, A., 2015. Adenosine $A_{2 B}$ receptor activation stimulates glucose uptake in the mouse forebrain. Purinergic Signal. 11, 561-569.

Lemos, C., Valério-Fernandes, A., Ghisleni, G.C., Ferreira, S.G., Ledent, C., de Ceballos, M.L., Köfalvi, A., 2012. Impaired hippocampal glucoregulation in the cannabinoid $\mathrm{CB}_{1}$ receptor knockout mice as revealed by an optimized in vitro experimental approach. J. Neurosci. Methods 204, 366-373. doi:10.1016/j.jneumeth.2011.11.028

Liu, S., Labouèbe, G., Karunakaran, S., Clee, S.M., Borgland, S.L., 2013. Effect of insulin on excitatory synaptic transmission onto dopamine neurons of the ventral tegmental area in a mouse model of hyperinsulinemia. Nutr. Diabetes 3, e97. doi: 10.1038/nutd.2013.38.

Lundgaard, I., Li, B., Xie, L., Kang, H., Sanggaard, S., Haswell, J.D., Sun, W., Goldman, S., Blekot, S., Nielsen, M., Takano, T., Deane, R., Nedergaard, M., 2015. Direct neuronal glucose uptake heralds activity-dependent increases in cerebral metabolism. Nat. Commun. 6, 6807. doi: 10.1038/ncomms7807.

Maldonado, R., Robledo, P., Berrendero, F., 2013. Endocannabinoid system and drug addiction: new insights from mutant mice approaches. Curr. Opin. Neurobiol. 23, 480486. doi:10.1016/j.conb.2013.02.004

Marques, J.M., Rodrigues, R.J., Valbuena, S., Rozas, J.L., Selak, S., Marin, P., Aller, M.I., Lerma, J., 2013. CRMP2 tethers kainate receptor activity to cytoskeleton dynamics during neuronal maturation. J. Neurosci. 33, 18298-18310. doi:10.1523/JNEUROSCI.313613.2013

Matias, I., Marzo, V.D., Köfalvi, A., 2008. Endocannabinoids in Energy Homeostasis and Metabolic Disorders, in: Köfalvi, A. (Ed.), Cannabinoids and the Brain. Springer US, pp. $277-316$.

Mátyás, F., Yanovsky, Y., Mackie, K., Kelsch, W., Misgeld, U., Freund, T.F. (2007). Subcellular localization of type 1 cannabinoid receptors in the rat basal ganglia. Neuroscience 137, 337-361.

McGrath, J.C., Drummond, G.B., McLachlan, E.M., Kilkenny, C., Wainwright, C.L., 2010. Guidelines for reporting experiments involving animals: the ARRIVE guidelines. Br. J. Pharmacol. 160, 1573-1576. doi:10.1111/j.1476-5381.2010.00873.x 
McGregor, G., Malekizadeh, Y., Harvey, J., 2015. Minireview: Food for thought: regulation of synaptic function by metabolic hormones. Mol. Endocrinol. 29, 3-13. doi: 10.1210/me.2014-1328.

McNay, E.C., Ong, C.T., McCrimmon, R.J., Cresswell, J., Bogan, J.S., Sherwin, R.S., 2010. Hippocampal memory processes are modulated by insulin and high-fat-induced insulin resistance. Neurobiol. Learn. Mem. 93, 546-553. doi:10.1016/j.nlm.2010.02.002

Meye, F.J., Adan, R.A.H., 2014. Feelings about food: the ventral tegmental area in food reward and emotional eating. Trends Pharmacol. Sci. 35, 31-40. doi:10.1016/j.tips.2013.11.003

Meye, F.J., Trezza, V., Vanderschuren, L.J.M.J., Ramakers, G.M.J., Adan, R. a. H., 2013. Neutral antagonism at the cannabinoid 1 receptor: a safer treatment for obesity. Mol. Psychiatry 18, 1294-1301. doi:10.1038/mp.2012.145

Molnár, G., Faragó, N., Kocsis, Á.K., Rózsa, M., Lovas, S., Boldog, E., Báldi, R., Csajbók, É., Gardi, J., Puskás, L.G., Tamás, G., 2014. GABAergic neurogliaform cells represent local sources of insulin in the cerebral cortex. J. Neurosci. 34, 1133-1137. doi:10.1523/JNEUROSCI.4082-13.2014

Murataeva, N., Straiker, A., Mackie, K., 2014. Parsing the players: 2-arachidonoylglycerol synthesis and degradation in the CNS. Br. J. Pharmacol. 171, 1379-1391. doi:10.1111/bph.12411

O’Dell, L.E., Natividad, L.A., Pipkin, J.A., Roman, F., Torres, I., Jurado, J., Torres, O.V., Friedman, T.C., Tenayuca, J.M., Nazarian, A., 2014. Enhanced nicotine selfadministration and suppressed dopaminergic systems in a rat model of diabetes. Addict. Biol. 19, 1006-1019. doi:10.1111/adb.12074

Pacold, S.T., Blackard, W.G., 1979. Central nervous system insulin receptors in normal and diabetic rats. Endocrinology 105, 1452-1457. doi:10.1210/endo-105-6-1452

Palomäki, V.A.B., Lehtonen, M., Savinainen, J.R., Laitinen, J.T., 2007. Visualization of 2arachidonoylglycerol accumulation and cannabinoid $\mathrm{CB}_{1}$ receptor activity in rat brain cryosections by functional autoradiography. J. Neurochem. 101, 972-981. doi:10.1111/j.1471-4159.2006.04403.x 
Patel, A.B., Lai, J.C., Chowdhury, G.M., Hyder, F., Rothman, D.L., Shulman, R.G., Behar, K.L., 2014. Direct evidence for activity-dependent glucose phosphorylation in neurons with implications for the astrocyte-to-neuron lactate shuttle. Proc. Natl. Acad. Sci. U S A. 111, 5385-5390. doi: 10.1073/pnas.1403576111.

Pellerin, L., Magistretti, P.J., 1994. Glutamate uptake into astrocytes stimulates aerobic glycolysis: a mechanism coupling neuronal activity to glucose utilization. Proc. Natl. Acad. Sci. U. S. A. 91, 10625-10629.

Pertwee, R.G., 2005. Inverse agonism and neutral antagonism at cannabinoid $\mathrm{CB}_{1}$ receptors. Life Sci. 76, 1307-1324.

Potter, G.M., Moshirfar, A., Castonguay, T.W., 1999. Insulin affects dopamine overflow in the nucleus accumbens and the striatum. Physiol. Behav. 65, 811-816.

Pickel, V.M., Chan, J., Kearn, C.S., Mackie, K., 2006. Targeting dopamine $\mathrm{D}_{2}$ and cannabinoid-1 $\left(\mathrm{CB}_{1}\right)$ receptors in rat nucleus accumbens. J. Comp. Neurol. 495, 299-313.

Robbe, D., Alonso, G., Manzoni, O.J., 2003. Exogenous and endogenous cannabinoids control synaptic transmission in mice nucleus accumbens. Ann. N. Y. Acad. Sci. 1003, 212-225. doi:10.1196/annals.1300.013

Rozenfeld, R., Devi, L. A., 2008. Regulation of $\mathrm{CB}_{1}$ cannabinoid receptor trafficking by the adaptor protein AP-3. FASEB J 22, 2311-2322. doi:10.1096/fj.07-102731

Schmidt, K., Lucignani, G., Mori, K., Jay, T., Palombo, E., Nelson, T., Pettigrew, K., Holden, J.E., Sokoloff, L., 1989. Refinement of the kinetic model of the $2-\left[{ }^{14} \mathrm{C}\right]$ deoxyglucose method to incorporate effects of intracellular compartmentation in brain. J. Cereb. Blood Flow Metab. 9, 290-303. doi:10.1038/jcbfm.1989.47

Schulingkamp, R.J., Pagano, T.C., Hung, D., Raffa, R.B., 2000. Insulin receptors and insulin action in the brain: review and clinical implications. Neurosci. Biobehav. Rev. 24, 855872. doi:10.1016/S0149-7634(00)00040-3

Sotiropoulos, I., Cerqueira, J.J., Catania, C., Takashima, A., Sousa, N., Almeida, O.F.X., 2008. Stress and glucocorticoid footprints in the brain-the path from depression to Alzheimer's disease. Neurosci. Biobehav. Rev. 32, 1161-1173. doi:10.1016/j.neubiorev.2008.05.007 
Sperlágh, B., Windisch, K., Andó, R.D., Vizi. E.S, 2009. Neurochemical evidence that stimulation of $\mathrm{CB}_{1}$ cannabinoid receptors on GABAergic nerve terminals activates the dopaminergic reward system by increasing dopamine release in the rat nucleus accumbens. Neurochem. Int. 54, 452-457. doi: 10.1016/j.neuint.2009.01.017.

Stouffer, M.A., Woods, C.A., Patel, J.C., Lee, C.R., Witkovsky, P., Bao, L., Machold, R.P., Jones, K.T., de Vaca, S.C., Reith, M.E., Carr, K.D., Rice, M.E., 2015. Insulin enhances striatal dopamine release by activating cholinergic interneurons and thereby signals reward. Nat. Commun. 6, 8543. doi: 10.1038/ncomms9543.

Tellez, L.A., Han, W., Zhang, X., Ferreira, T.L., Perez, I.O., Shammah-Lagnado, S.J., van den Pol, A.N., de Araujo, I.E., 2016. Separate circuitries encode the hedonic and nutritional values of sugar. Nat. Neurosci. 19, 465-470. doi: 10.1038/nn.4224.

Thompson, E.E., Jagielo-Miller, J.E., Vemuri, V.K., Makriyannis, A., McLaughlin, P.J., 2016. $\mathrm{CB}_{1}$ antagonism produces behaviors more consistent with satiety than reduced reward value in food-maintained responding in rats. J. Psychopharmacol. 30, 482-491. doi: $10.1177 / 0269881116639287$

Uemura, E., Greenlee, H.W., 2006. Insulin regulates neuronal glucose uptake by promoting translocation of glucose transporter GLUT3. Exp. Neurol. 198, 48-53. doi:10.1016/j.expneurol.2005.10.035

Varela, L., Horvath, T.L., 2012. Leptin and insulin pathways in POMC and AgRP neurons that modulate energy balance and glucose homeostasis. EMBO Rep. 13, 1079-1086. doi: 10.1038/embor.2012.174.

Volkow, N.D., Wang, G.-J., Fowler, J.S., Telang, F., 2008. Overlapping neuronal circuits in addiction and obesity: evidence of systems pathology. Philos. Trans. R. Soc. Lond. B. Biol. Sci. 363, 3191-3200. doi:10.1098/rstb.2008.0107

Webster, N.J.G., Park, K., Pirrung, M.C., 2003. Signaling effects of demethylasterriquinone B1, a selective insulin receptor modulator. Chembiochem Eur. J. Chem. Biol. 4, 379-385. doi:10.1002/cbic. 200200468

Werner, H., Raizada, M.K., Mudd, L.M., Foyt, H.L., Simpson, I.A., Roberts, C.T., LeRoith, D., 1989. Regulation of rat brain/HepG2 glucose transporter gene expression by insulin 
and insulin-like growth factor-I in primary cultures of neuronal and glial cells. Endocrinology 125, 314-320. doi:10.1210/endo-125-1-314

Werther, G.A., Hogg, A., Oldfield, B.J., McKinley, M.J., Figdor, R., Allen, A.M., Mendelsohn, F.A., 1987. Localization and characterization of insulin receptors in rat brain and pituitary gland using in vitro autoradiography and computerized densitometry. Endocrinology 121, 1562-1570. doi:10.1210/endo-121-4-1562

Werther, G.A., Hogg, A., Oldfield, B.J., McKinley, M.J., Figdor, R., Mendelsohn, F.A., 1989. Localization and Characterization of Insulin-Like Growth Factor-I Receptors in Rat Brain and Pituitary Gland Using in vitro Autoradiography and Computerized Densitometry* A Distinct Distribution from Insulin Receptors. J. Neuroendocrinol. 1, 369-377. doi:10.1111/j.1365-2826.1989.tb00131.x

Williams, D.B., 2008. A novel, rapid, inhibitory effect of insulin on $\alpha 1 \beta 2 \gamma 2 \mathrm{~s} \gamma$-aminobutyric acid type A receptors. Neurosci. Lett. 443, 27-31. doi:10.1016/j.neulet.2008.07.038.

Winters, B.D., Krüger, J.M., Huang, X., Gallaher, Z.R., Ishikawa, M., Czaja, K., Krueger, J.M., Huang, Y.H., Schlüter, O.M., Dong, Y., 2012. Cannabinoid receptor 1-expressing neurons in the nucleus accumbens. Proc. Natl. Acad. Sci. U. S. A. 109, E2717-2725. doi:10.1073/pnas.1206303109 


\section{Legends to figures}

Fig. 1 Insulin receptor activation stimulates glucose uptake in acute accumbal slices from the rat. (A) Flow-chart depicting the experimental steps in the principal assay and their timing. Abbreviations: dexa, dexamethasone; DMAQB1, demethylasterriquinone B1 THL, tetrahydrolipstatin; WIN, WIN55212-2. DMSO (0.1\%) was given as vehicle control in place of the lipophilic compounds in the same time. (B) Insulin, rather than IGF-1 receptors mediate the action of insulin on glucose uptake. Bars represent the mean \pm S.E.M. of $n \geq 7$ independent observations (rats). The control values from each experiment are averaged and taken as $100 \%$, while effect amplitudes are normalized to the appropriate controls. Due to the relative comparison, the ordinate is preferably labeled as $\left[{ }^{3} \mathrm{H}\right] \mathrm{DG}\left(\left[{ }^{3} \mathrm{H}\right]\right.$ deoxyglucose $)$ uptake which is more exact than glucose uptake, although the two are used interchangeably in this study. $* P<0.05, * * * P<0.001$, n.s., not significant.

Fig. 2 Release diagrams and relative values of the release of $\left[{ }^{3} \mathrm{H}\right] \mathrm{GABA}$ and $\left[{ }^{14} \mathrm{C}\right]$ glutamate in rat accumbal slices. Insulin was administered in the superfusion medium according to the horizontal bars. $\mathrm{FR} \%$, fractional release \%, i.e. the release value relative to the total radioactivity content in the slice at the given time-point. All data are mean \pm S.E.M. of $n=4$, in duplicate.

Fig. 3 Glucocorticoid receptor activation prevents insulin from stimulating glucose uptake. Bars represent the mean \pm S.E.M. of $\mathrm{n} \geq 6$ independent observations (rats). Abbreviations; dexa, dexamethasone; spirono, spironolactone $(10 \mu \mathrm{M})$. ${ }^{*} P<0.05, * * * P<0.001$, n.s., not significant.

Fig. $4 \mathrm{CB}_{1}$ cannabinoid receptors mediate the anti-insulin action of dexamethasone. While the synthetic cannabinoid agonist, WIN55212-2 (500 nM) and the $\mathrm{CB}_{1} \mathrm{R}$ antagonists, O-2050 $(500 \mathrm{nM})$ and SR141716A (500 nM) had no effect on glucose uptake per se (Table 1), WIN55212-2 prevented insulin from stimulating glucose uptake. Both $\mathrm{CB}_{1} \mathrm{R}$ antagonists 
opposed the anti-insulin action of dexamethasone $(10 \mu \mathrm{M})$. The diacylglycerol lipase inhibitor, tetrahydrolipstatin (THL, $10 \mu \mathrm{M}$ ) mimicked the effect of the $\mathrm{CB}_{1} \mathrm{R}$ antagonists. Finally, the $\alpha, \beta$ HD6/12 inhibitor, WWL70 $(1 \mu \mathrm{M})$ but not that the monoacylglycerol lipase inhibitor, JZL184 (1 $\mu \mathrm{M})$ mimicked the anti-insulin action of dexamethasone, thus supporting the involvement of 2-AG in the glucocorticoid-induced insulin resistance. Bars represent the mean \pm S.E.M. of $\mathrm{n} \geq 6$ independent observations (rats). ${ }^{*} P<0.05,{ }^{* *} P<0.01,{ }^{* * *} P<$ 0.001 , n.s., not significant.

Fig. 5 The $\mathrm{CB}_{1} \mathrm{R}$ was readily detected at around $53 \mathrm{kDa}$ molecular weight, and enriched in complexes immunoprecipitated with the anti-insulin receptor $\beta$-chain antibody (anti-InsR $\beta$; Sigma-Aldrich), but not with rabbit polyclonal IgG (44 kDa). InsR $\beta$ was detected at $95 \mathrm{kDa}$ (with a different anti-InsR $\beta$ antibody from Santa-Cruz Biotechnology). 
Table 1 Effect of treatments on $\left[{ }^{3} \mathrm{H}\right] \mathrm{DG}$ uptake in acute slices

\begin{tabular}{rccc}
\multicolumn{1}{c}{ treatment } & mean \pm S.E.M. & n & $\boldsymbol{P}$ vs. 100 \\
\hline dexamethasone $(1 \mu \mathrm{M})$ & $94.9 \pm 11.3$ & 6 & 0.669 \\
dexamethasone $(10 \mu \mathrm{M})$ & $108.6 \pm 6.55$ & 8 & 0.228 \\
I-OMe-tyrphostin AG 538 $(5 \mu \mathrm{M})$ & $104.1 \pm 6.2$ & 8 & 0.523 \\
JZL184 $(1 \mu \mathrm{M})$ & $88.9 \pm 8.8$ & 6 & 0.261 \\
mifepristone $(10 \mu \mathrm{M})$ & $101.3 \pm 16.5$ & 7 & 0.940 \\
O-2050 $(500 \mathrm{nM})$ & $106.9 \pm 7.3$ & 22 & 0.357 \\
spironolactone $(10 \mu \mathrm{M})$ & $120.9 \pm 7.8$ & 7 & $0.036 *$ \\
SR141716A $(500 \mathrm{nM})$ & $87.0 \pm 10.8$ & 8 & 0.266 \\
tetrahydrolipstatin $(10 \mu \mathrm{M})$ & $102.65 \pm 9.9$ & 10 & 0.795 \\
WIN55212-2 $(500 \mathrm{nM})$ & $106.4 \pm 10.3$ & 11 & 0.550 \\
WWL70 $(1 \mu \mathrm{M})$ & $94.1 \pm 3.2$ & 5 & 0.137 \\
\hline & & &
\end{tabular}




\section{Figure 1}
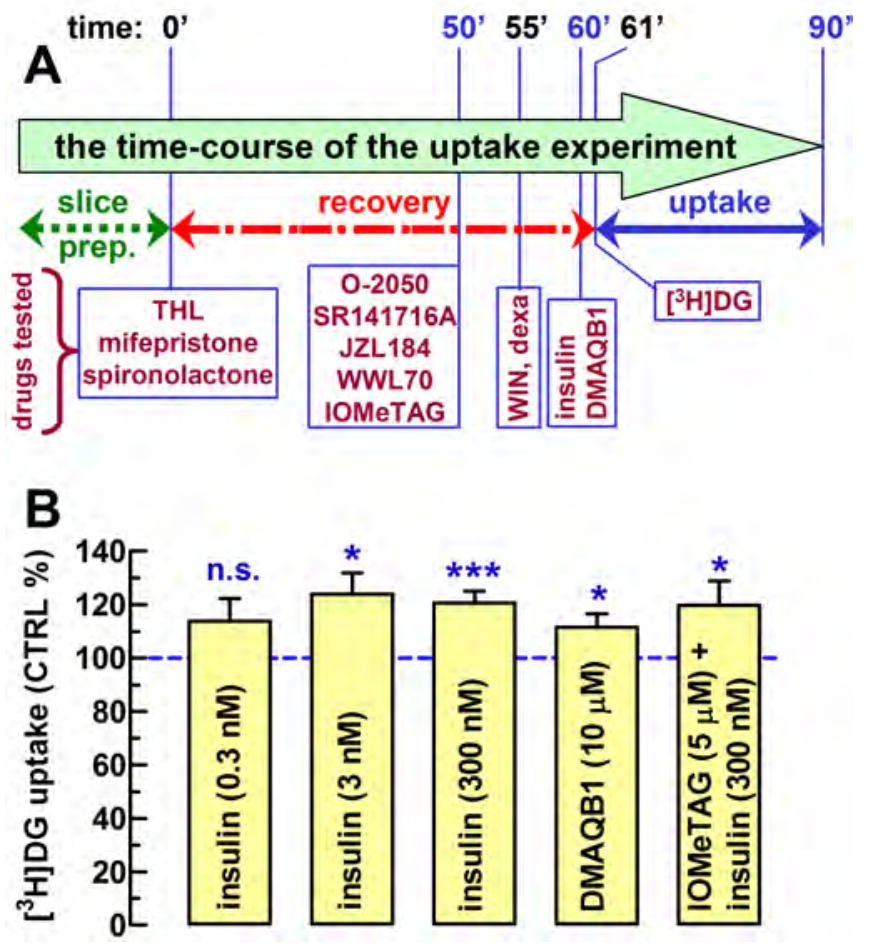
Figure 2

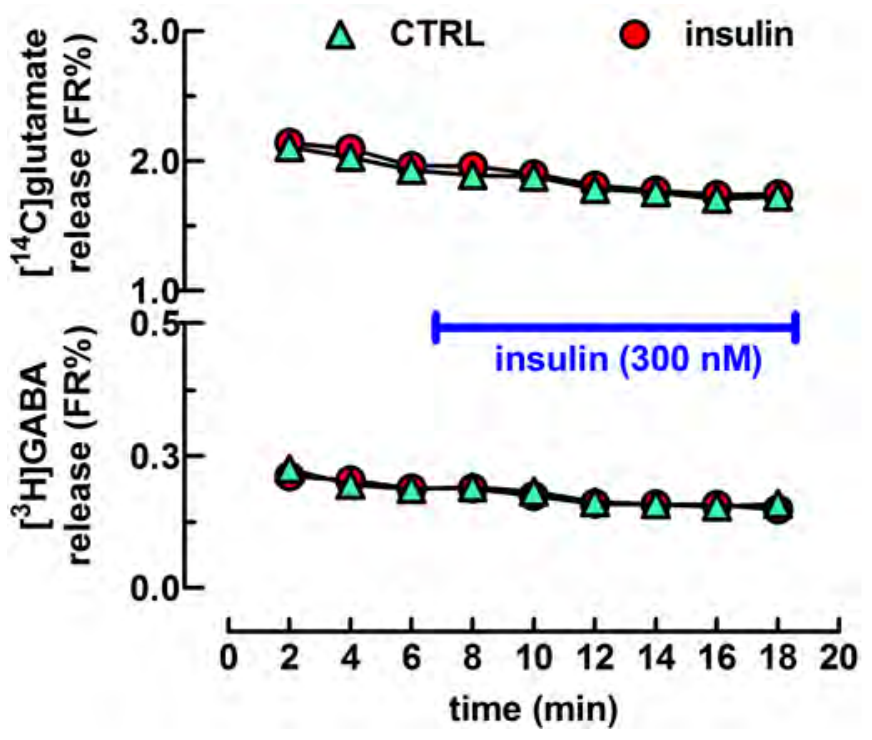


Figure 3

\section{$\square$ insulin (300 nM) +}

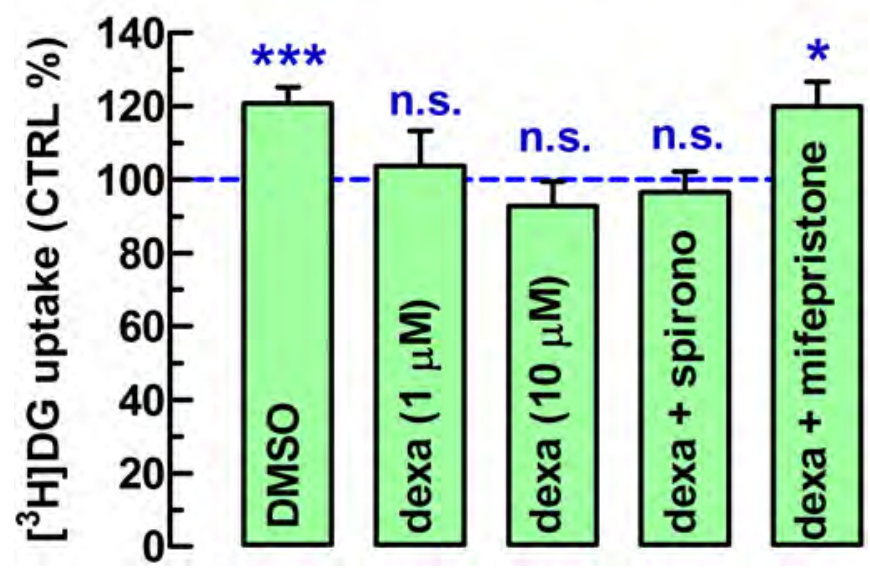


Figure 4

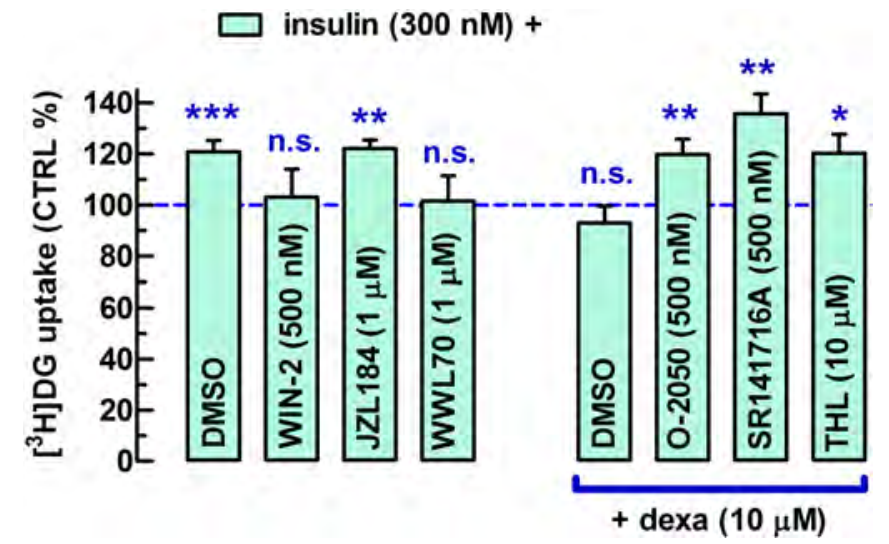


Figure 5

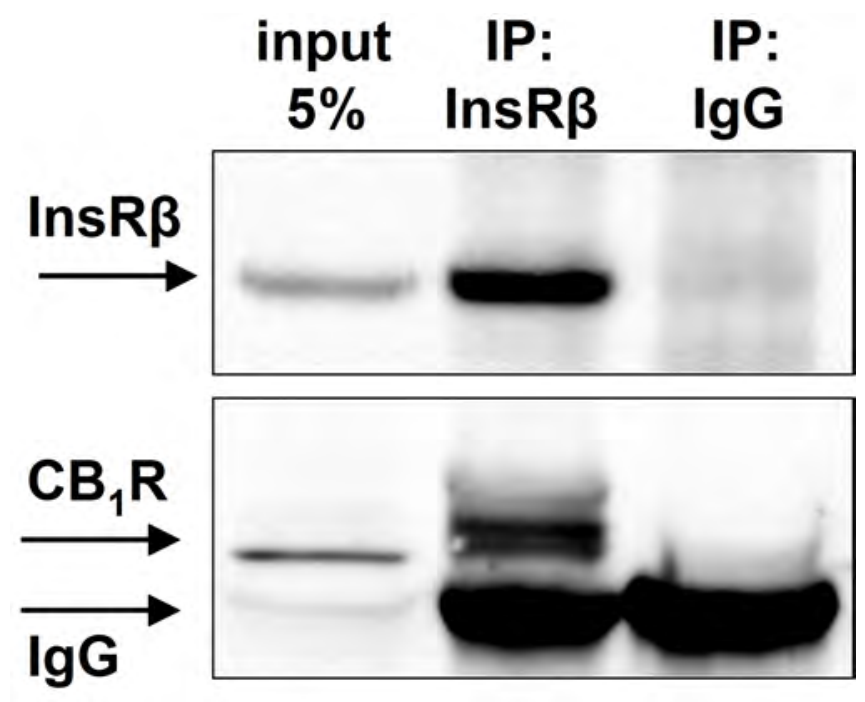

